\title{
Improving the Seventh Grade Students' Speaking Ability Through Card Games
}

\author{
Yeyensi Meika Sari ${ }^{1 *}$
}

\author{
${ }^{I}$ SMP Satu Atap Tanjung Kurung, OKU \\ *Corresponding author. E-mail: yeyensimeikasari@gmail.com
}

\begin{abstract}
The title of this research was improving the seventh' grade students speaking ability through card games. This research is Classroom Action Research (CAR). CAR as an enquiry, undertaken with finding out and understanding to refine practice constantly; the emerging evidence-based outcomes will then contribute to the researching practitioner's continuing professional development. This study's population comprises Satu Atap State Junior High School Tanjung Kurung, OKU Selatan, which a total number is 48 students. The instrument used in this research is a test. A speaking test is done to measure the students' speaking ability. Card game strategy can improve the students' speaking ability of the seventh-grade students of Satap State Junior High School of Tanjung Kurung, OKU Selatan. It could be reached in Cycle III. Seventeen students (85\%) met the standard score of 70, and the average score or mean was 1531(76,55\%). In Cycle III, she used another variation of the procedure of Card Game Strategy.
\end{abstract}

Keywords: Improving Student's Skill, Card Games, Speaking Skill.

\section{INTRODUCTION}

Speaking is defined as a tool to interact with others to express opinions, ideas, emotional state, etc. Also, sharing information between people, exchanging, solving problems, and retaining social relationships and friendships [1]. One of the factors that influence students to learn speaking is motivation. This seems to have an essential role in increasing students' speaking ability. Motivated students will do everything which supports their performance [2].

On the other hand, every student has various speaking perspectives and has perceived speaking in the same feeling. A lot of students judge speaking as a complex subject to be learned and have many factors that cause them to get problems in learning speaking. For example, most of them are lack vocabulary as not knowing what to say in English [3]. Most of them are shocked and disappointed when they practice English in real communication. They have not been prepared for spontaneous interaction, and also they confused. They are even wordless and need help when the teacher asks a straightforward question, as "where have you been?"

Suggested that speech rating tasks, in which students rate conversations or dialogues on various formality conditions and the like, can increase awareness about language and help transfer this information to production activities such as role-play [4]. Encouraging students to speak English requires appropriate creativity to participate them in conversation. The card costs less and is achievable for all teachers. Those who live in a suburb and their school have no budget for learning tools media such as a computer, language lab, etc. Also, the card is more straightforward, user-friendly, attractive, and obtainable everywhere [5].

\section{The objective of the study}

This study aims to investigate the improvement of seventh-grade students' speaking ability through the application of card games at Satap state junior high school of Tanjung Kurung, OKU Selatan: Classroom Action Research.

\section{Significance of the Study}

1. The students will increase their motivation through speaking ability. Besides, the new technique will raise the students' interest as well as creativity in speaking activities.

2. It will give the teacher a broader view of teaching speaking ability in the classroom using a new technique rather than a traditional technique that they already know for years. 
3. It can be used as a reference for other researchers who are concerned about conducting a similar study.

\section{METHODS}

The researcher uses Classroom Action Research (CAR). CAR as an enquiry, undertaken with finding out and understanding to refine practice constantly. The emerging evidence-based outcomes would then contribute to the researching practitioner's continuing professional development, with the instrument used in this research is a test.

\section{Population}

The population is "a group of individuals (or a group of organizations) with some common defining characteristic that the researcher can identify and study."

Table 1. The Population Research

\begin{tabular}{|c|c|c|c|c|}
\hline \multirow{2}{*}{ No } & \multirow{2}{*}{ Class } & \multicolumn{2}{|c|}{ Number of Students } & \multirow{2}{*}{ Total } \\
\cline { 3 - 4 } & & Male & Female & \\
\cline { 3 - 4 } & & 11 & 9 & 20 \\
\hline 1. & VII & 9 & 8 & 17 \\
\hline 2. & VIII & 5 & 6 & 11 \\
\hline 3. & IX & 25 & 23 & 48 \\
\hline & Total & & & \\
\hline
\end{tabular}

Source: Satu Atap of State Junior High School Tanjung Kurung OKU Selatan in academic 2020/2021

\section{Sample}

The sample was the seventh-grade students at Satu Atap State Junior High School Tanjung Kurung OKU Selatan is VII.

\section{Data Collection}

The instruments used in this research will be tests and observation. The writing test will give to measure the students' speaking ability. The data from observation were analyzed by percentage analysis in which to strengthen the data finding of card game used.

$$
P=\frac{F}{N} \times 100 \%
$$

Lagend:

$\mathrm{P} \quad$ : Percentage of the answer

F : The Total number of the answer

$\mathrm{N} \quad$ : The total number of the sample.

\section{Data Analysis}

The data were analyzed from observation, students' test of speaking, reports, presentations, and scores from every implementation of the research cycle. This will be analyzed in a descriptive manner and score from using presentation techniques to see trends in learning activities. This will be described in word form. Minimum Criteria of Completeness (KKM) classical is using the formula:

$$
K B=\frac{N}{S} \times 100 \%
$$

KB : The percentage of students' learning completeness

$\mathrm{N}$ : The number of students who received grades $\geq$ 70

$\mathrm{S} \quad$ : The number of students

\section{RESULTS AND DISCUSSION}

Table 2. The Students' Learning Activity in Cycle 1

\begin{tabular}{|c|l|c|c|}
\hline \multirow{2}{*}{ No } & \multicolumn{1}{|c|}{ Explanation } & \multicolumn{2}{|c|}{ Cycle 1 } \\
\cline { 3 - 4 } & $\begin{array}{c}\text { Number of } \\
\text { Students }\end{array}$ & Percentage \\
\hline 1. & $\begin{array}{l}\text { The Students Actively } \\
\text { Involved }\end{array}$ & 6 & $30 \%$ \\
\hline 2. & $\begin{array}{l}\text { The Students Inactively } \\
\text { Involved }\end{array}$ & 9 & $45 \%$ \\
\hline 3. & $\begin{array}{l}\text { The Students not } \\
\text { Involved }\end{array}$ & 5 & $25 \%$ \\
\hline
\end{tabular}

Table 3. The result of Students' Learning Activity in

\begin{tabular}{|c|c|c|c|}
\hline No & $\begin{array}{l}\text { Students } \\
\text { Number }\end{array}$ & Score & Explanation \\
\hline 1 & 01 & 75 & Met the criteria of success \\
\hline 2 & 02 & 55 & $\begin{array}{l}\text { Did not meet the criteria of the } \\
\text { standard }\end{array}$ \\
\hline 3 & 03 & 67 & $\begin{array}{l}\text { Did not meet the criteria of the } \\
\text { standard }\end{array}$ \\
\hline 4 & 04 & 65 & $\begin{array}{l}\text { Did not meet the criteria of the } \\
\text { standard }\end{array}$ \\
\hline 5 & 05 & 70 & Met the criteria of success \\
\hline 6 & 06 & 60 & $\begin{array}{l}\text { Did not meet the criteria of the } \\
\text { standard }\end{array}$ \\
\hline 7 & 07 & 50 & $\begin{array}{l}\text { Did not meet the criteria of the } \\
\text { standard }\end{array}$ \\
\hline 8 & 08 & 68 & $\begin{array}{l}\text { Did not meet the criteria of the } \\
\text { standard }\end{array}$ \\
\hline 9 & 09 & 64 & $\begin{array}{l}\text { Did not meet the criteria of the } \\
\text { standard }\end{array}$ \\
\hline 10 & 010 & 80 & Met the criteria of success \\
\hline 11 & 011 & 50 & $\begin{array}{l}\text { Did not meet the criteria of the } \\
\text { standard }\end{array}$ \\
\hline 12 & 012 & 58 & $\begin{array}{l}\text { Did not meet the criteria of the } \\
\text { standard }\end{array}$ \\
\hline 13 & 013 & 68 & $\begin{array}{l}\text { Did not meet the criteria of the } \\
\text { standard }\end{array}$ \\
\hline 14 & 014 & 65 & $\begin{array}{l}\text { Did not meet the criteria of the } \\
\text { standard }\end{array}$ \\
\hline 15 & 015 & 77 & Met the criteria of success \\
\hline 16 & 016 & 65 & $\begin{array}{l}\text { Did not meet the criteria of the } \\
\text { standard }\end{array}$ \\
\hline 17 & 017 & 75 & Met the criteria of success \\
\hline 18 & 018 & 66 & $\begin{array}{l}\text { Did not meet the criteria of the } \\
\text { standard }\end{array}$ \\
\hline 19 & 019 & 76 & Met the criteria of success \\
\hline 20 & 020 & 55 & $\begin{array}{l}\text { Did not meet the criteria of the } \\
\text { standard }\end{array}$ \\
\hline & & 1309 & \\
\hline & & 65,45 & \\
\hline
\end{tabular}
Cycle I

Based on the Cycle I test score, the writer concluded that the mean of the students speaking ability was $1309(65,45 \%)$. Most of the students who had met the minimal standard criteria were six students or $30 \%$. Moreover, the students' speaking ability score in Cycle I 
test had not met the minimal standard criteria. There were 14 or $70 \%$ who got a score less than 70 . It might be caused by a lack of knowledge of speaking aspects (Pronunciation, Fluency, Expression, and Vocabulary).

Table 4. The Students' Learning Activity in Cycle II

\begin{tabular}{|c|l|c|c|}
\hline \multirow{2}{*}{ No } & \multirow{2}{*}{ Explanation } & \multicolumn{2}{|c|}{ Cycle II } \\
\cline { 3 - 4 } & $\begin{array}{c}\text { Number of } \\
\text { Students }\end{array}$ & Percentage \\
\hline 1. & $\begin{array}{l}\text { The Students } \\
\text { Actively Involved }\end{array}$ & 11 & $55 \%$ \\
\hline 2. & $\begin{array}{l}\text { The Students } \\
\text { Inactively Involved }\end{array}$ & 5 & $25 \%$ \\
\hline 3. & $\begin{array}{l}\text { The Students not } \\
\text { Involved }\end{array}$ & 4 & $20 \%$ \\
\hline
\end{tabular}

Table 5. The result of Students' Learning Activity in Cycle II

\begin{tabular}{|c|c|c|c|}
\hline No & $\begin{array}{l}\text { Students } \\
\text { Number }\end{array}$ & Score & Explanation \\
\hline 1 & 01 & 80 & Met the criteria of success \\
\hline 2 & 02 & 50 & $\begin{array}{l}\text { Did not meet the criteria of the } \\
\text { standard }\end{array}$ \\
\hline 3 & 03 & 74 & Met the criteria of success \\
\hline 4 & 04 & 65 & $\begin{array}{l}\text { Did not meet the criteria of the } \\
\text { standard }\end{array}$ \\
\hline 5 & 05 & 75 & Met the criteria of success \\
\hline 6 & 06 & 60 & $\begin{array}{l}\text { Did not meet the criteria of the } \\
\text { standard }\end{array}$ \\
\hline 7 & 07 & 50 & $\begin{array}{l}\text { Did not meet the criteria of the } \\
\text { standard }\end{array}$ \\
\hline 8 & 08 & 65 & $\begin{array}{l}\text { Did not meet the criteria of the } \\
\text { standard }\end{array}$ \\
\hline 9 & 09 & 74 & Met the criteria of success \\
\hline 10 & 010 & 80 & Met the criteria of success \\
\hline 11 & 011 & 75 & Met the criteria of success \\
\hline 12 & 012 & 78 & Met the criteria of success \\
\hline 13 & 013 & 58 & $\begin{array}{l}\text { Did not meet the criteria of the } \\
\text { standard }\end{array}$ \\
\hline 14 & 014 & 65 & $\begin{array}{l}\text { Did not meet the criteria of the } \\
\text { standard }\end{array}$ \\
\hline 15 & 015 & 80 & Met the criteria of success \\
\hline 16 & 016 & 70 & Met the criteria of success \\
\hline 17 & 017 & 75 & Met the criteria of success \\
\hline 18 & 018 & 66 & $\begin{array}{l}\text { Did not meet the criteria of the } \\
\text { standard }\end{array}$ \\
\hline 19 & 019 & 77 & Met the criteria of success \\
\hline 20 & 020 & 55 & $\begin{array}{l}\text { Did not meet the criteria of the } \\
\text { standard }\end{array}$ \\
\hline & Amount & 1372 & \\
\hline & Average & 68,6 & \\
\hline
\end{tabular}

Table 6. The Percentage of Students' Learning Mastery in Cycle II

\begin{tabular}{|c|c|c|c|}
\hline \multirow[b]{2}{*}{ No } & \multirow[b]{2}{*}{ Explanation } & \multicolumn{2}{|c|}{ Cycle II } \\
\hline & & $\begin{array}{l}\text { Number of } \\
\text { Students }\end{array}$ & Percentage \\
\hline 1. & $\begin{array}{l}\text { Students who met the } \\
\text { criteria of minimal } \\
\text { standard }\end{array}$ & 11 & $55 \%$ \\
\hline 2. & $\begin{array}{l}\text { Students who did not } \\
\text { meet the criteria of the } \\
\text { standard }\end{array}$ & 9 & $45 \%$ \\
\hline
\end{tabular}

Based on the Cycle II test score, the total score was $1372(68,6 \%)$, and the students who had met the criteria of the minimal standard were 11 students or
$55 \%$. Most of the students' speaking ability scores in the Cycle II test had met the criteria of minimal standard 70. Moreover, there were $45 \%$ of students scored less than 70. Following Cycle II test result, it had got progress to the number of students who had reached the criteria of minimal standard from 6 to 11 students, but it was still needed to have to treat in Cycle III to improve students' speaking ability by using card game strategy. Some weaknesses in Cycle II would be improved in Cycle III.

Table 7. The Students' Learning Activity in Cycle III

\begin{tabular}{|c|l|c|c|}
\hline \multirow{2}{*}{ No } & \multirow{2}{*}{ Explanation } & \multicolumn{2}{|c|}{ Cycle III } \\
\cline { 3 - 4 } & & $\begin{array}{c}\text { Number of } \\
\text { Students }\end{array}$ & Percentage \\
\hline 1. & $\begin{array}{l}\text { The Students } \\
\text { Actively Involved }\end{array}$ & 17 & $85 \%$ \\
\hline 2. & $\begin{array}{l}\text { The Students } \\
\text { Inactively } \\
\text { Involved }\end{array}$ & 3 & $15 \%$ \\
\hline 3. & $\begin{array}{l}\text { The Students not } \\
\text { Involved }\end{array}$ & 0 & $0 \%$ \\
\hline
\end{tabular}

Table 8. The Result of Cycle III

\begin{tabular}{|c|c|c|c|}
\hline No & $\begin{array}{l}\text { Students } \\
\text { Number }\end{array}$ & Score & Explanation \\
\hline 1 & 01 & 85 & Met the criteria of success \\
\hline 2 & 02 & 76 & Met the criteria of success \\
\hline 3 & 03 & 80 & Met the criteria of success \\
\hline 4 & 04 & 75 & Met the criteria of success \\
\hline 5 & 05 & 80 & Met the criteria of success \\
\hline 6 & 06 & 77 & Met the criteria of success \\
\hline 7 & 07 & 66 & $\begin{array}{l}\text { Did not meet the criteria } \\
\text { of the standard }\end{array}$ \\
\hline 8 & 08 & 75 & Met the criteria of success \\
\hline 9 & 09 & 80 & Met the criteria of success \\
\hline 10 & 010 & 85 & Met the criteria of success \\
\hline 11 & 011 & 80 & Met the criteria of success \\
\hline 12 & 012 & 80 & Met the criteria of success \\
\hline 13 & 013 & 60 & $\begin{array}{l}\text { Did not meet the criteria } \\
\text { of the standard }\end{array}$ \\
\hline 14 & 014 & 75 & Met the criteria of success \\
\hline 15 & 015 & 85 & Met the criteria of success \\
\hline 16 & 016 & 77 & Met the criteria of success \\
\hline 17 & 017 & 80 & Met the criteria of success \\
\hline 18 & 018 & 75 & Met the criteria of success \\
\hline 19 & 019 & 80 & Met the criteria of success \\
\hline 20 & 020 & 60 & $\begin{array}{l}\text { Did not meet the criteria } \\
\text { of the standard }\end{array}$ \\
\hline & Amount & 1531 & \\
\hline & Average & 76,55 & \\
\hline
\end{tabular}

Table 9. The Percentage of Students' Learning Mastery in Cycle III

\begin{tabular}{|l|l|l|l|}
\hline \multirow{2}{*}{ No } & \multirow{2}{*}{ Explanation } & \multicolumn{2}{|c|}{ Cycle III } \\
\cline { 3 - 4 } & & $\begin{array}{l}\text { Number of } \\
\text { Students }\end{array}$ & Percentage \\
\hline 1. & $\begin{array}{l}\text { Students who met } \\
\text { the criteria of } \\
\text { minimal standard }\end{array}$ & 17 & $85 \%$ \\
\hline 2. & $\begin{array}{l}\text { Students who did } \\
\text { not meet the } \\
\text { criteria of the } \\
\text { standard }\end{array}$ & 3 & $15 \%$ \\
\hline
\end{tabular}


Based on the Cycle III test score presented in table 19 , the total score was1531 (76,55\%). Students who had met the criteria of the minimal standard were 17 students or $85 \%$. Most of the students' speaking ability scores in the Cycle III test had met the minimal standard criteria. There was only $15 \%$ of students got scores less than 70. The treatment in Cycle III to improve students' speaking ability worked well as this expectation.

Table 10. The Students' Achievement in the Three Cycles

\begin{tabular}{|l|c|c|c|}
\hline \multirow{2}{*}{ Achievement } & \multicolumn{3}{|c|}{ Cycles } \\
\cline { 2 - 4 } & I & II & III \\
\hline Mean & $1309(65,45 \%)$ & $1372(68,6 \%)$ & $1531(76,55 \%)$ \\
\hline Achievement & $30 \%$ & $55 \%$ & $85 \%$ \\
\hline
\end{tabular}

Based on the table above, the improvement of mean achievement in percentage proved that card game strategy important role in improving students' speaking ability.

\section{The Observation Interpretation}

Table 11. The Result of the Observation in Cycle I

\begin{tabular}{|c|c|c|c|c|}
\hline \multirow{2}{*}{$\begin{array}{c}\text { Items } \\
\text { Number }\end{array}$} & \multicolumn{2}{|c|}{ Students Answer } & \multicolumn{2}{c|}{ Percentage } \\
\cline { 2 - 5 } & Yes & No & Yes & No \\
\hline 1 & 14 & 6 & $70 \%$ & $30 \%$ \\
\hline 2 & 12 & 8 & $60 \%$ & $40 \%$ \\
\hline 3 & 9 & 11 & $45 \%$ & $55 \%$ \\
\hline 4 & 11 & 9 & $55 \%$ & $45 \%$ \\
\hline 5 & 8 & 12 & $40 \%$ & $60 \%$ \\
\hline 6 & 8 & 12 & $40 \%$ & $60 \%$ \\
\hline 7 & 9 & 11 & $45 \%$ & $55 \%$ \\
\hline 8 & 12 & 8 & $60 \%$ & $40 \%$ \\
\hline 9 & 7 & 13 & $35 \%$ & $65 \%$ \\
\hline 10 & 10 & 10 & $50 \%$ & $50 \%$ \\
\hline & & & $\mathbf{5 0 \%}$ & $\mathbf{5 0 \%}$ \\
\hline
\end{tabular}

Based on the table above, in Cycle I observation the $50 \%$ of students had high motivation and interest in learning English, especially speaking by using card game strategy, and $50 \%$ of students had low motivation.

Table 12. The Result of the Observation in Cycle II

\begin{tabular}{|c|c|c|c|c|}
\hline \multirow{2}{*}{$\begin{array}{c}\text { Items } \\
\text { Number }\end{array}$} & \multicolumn{2}{|c|}{ Students Answer } & \multicolumn{2}{c|}{ Percentage } \\
\cline { 2 - 5 } & Yes & No & Yes & No \\
\hline 1 & 15 & 5 & $75 \%$ & $25 \%$ \\
\hline 2 & 13 & 7 & $65 \%$ & $35 \%$ \\
\hline 3 & 13 & 7 & $65 \%$ & $35 \%$ \\
\hline 4 & 15 & 5 & $75 \%$ & $25 \%$ \\
\hline 5 & 11 & 9 & $55 \%$ & $45 \%$ \\
\hline 6 & 11 & 9 & $55 \%$ & $45 \%$ \\
\hline 7 & 11 & 9 & $55 \%$ & $45 \%$ \\
\hline 8 & 19 & 1 & $95 \%$ & $5 \%$ \\
\hline 9 & 10 & 10 & $50 \%$ & $50 \%$ \\
\hline 10 & 11 & 9 & $55 \%$ & $45 \%$ \\
\hline & & & $\mathbf{6 4 , 5 \%}$ & $\mathbf{3 5 , 5 \%}$ \\
\hline
\end{tabular}

Based on the table above, in the Cycle II observation, $64,5 \%$ of students had high motivation by using card game strategy, and $35,5 \%$ of students had low motivation.

Table 13. The Result of the Observation in Cycle III

\begin{tabular}{|c|c|c|c|c|}
\hline \multirow{2}{*}{$\begin{array}{c}\text { Items } \\
\text { Number }\end{array}$} & \multicolumn{2}{|c|}{ Students Answer } & \multicolumn{2}{c|}{ Percentage } \\
\cline { 2 - 5 } & Yes & No & Yes & No \\
\hline 1 & 18 & 2 & $90 \%$ & $10 \%$ \\
\hline 2 & 17 & 3 & $85 \%$ & $15 \%$ \\
\hline 3 & 16 & 4 & $80 \%$ & $20 \%$ \\
\hline 4 & 17 & 3 & $85 \%$ & $15 \%$ \\
\hline 5 & 12 & 8 & $60 \%$ & $40 \%$ \\
\hline 6 & 14 & 6 & $70 \%$ & $30 \%$ \\
\hline 7 & 14 & 6 & $70 \%$ & $30 \%$ \\
\hline 8 & 20 & 0 & $100 \%$ & $0 \%$ \\
\hline 9 & 15 & 5 & $75 \%$ & $25 \%$ \\
\hline 10 & 13 & 7 & $65 \%$ & $35 \%$ \\
\hline & & & $\mathbf{7 8 \%}$ & $\mathbf{2 2 \%}$ \\
\hline
\end{tabular}

Based on the table above, in the Cycle III observation, $78 \%$ of students had high motivation, and $22 \%$ had low motivation.

Table 14. The Result of the Students Learning Motivation in Three Cycles

\begin{tabular}{|c|c|c|c|}
\hline \multirow{2}{*}{ Motivation } & \multicolumn{3}{|c|}{ Cycles } \\
\cline { 2 - 4 } & I & II & III \\
\hline High & $30 \%$ & $55 \%$ & $78 \%$ \\
\hline Low & $70 \%$ & $45 \%$ & $22 \%$ \\
\hline
\end{tabular}

Based on the table above, it could be seen that in Cycle I, the result of the observation was $30 \%$ students had high motivation in learning speaking by using roleplay strategy, in the Cycle II was55\%. The Cycle III, the students who had high motivation, was $78 \%$. The increasing percentage showed the students' motivation to learn English increased after given treatment or action in Cycle I, II, and III.

\section{CONCLUSION}

Firstly, the card game strategy can improve the students' speaking ability of the seventh-grade students of Satap State Junior High School of Tanjung Kurung, OKU Selatan. It could be reached in Cycle III. Seventeen students $(85 \%)$ met the standard score of 70 , and the average score or mean was $1531(76,55 \%)$.

Secondly, based on the result of the observation sheet in Cycle I the students who had high motivation was $30 \%$ students had high motivation in learning speaking by using role-play strategy, in the Cycle II was $55 \%$, and the Cycle III the students who had high motivation, was $78 \%$. It was inferred that students' perception of card game strategy implementation to 
improve their speaking ability was very good, and they had high motivation to learn English.

\section{REFERENCES}

[1]. Harmer, J. (2001). The Practice of English Language Teaching. Malaysia:Longman.

[2]. Mardiyoko, T. (2013). "Kontribusi Kompetensi Profesional Guru dan Kreativitas Guru Terhadap Kinerja Guru dalam Pembelajaran Di SMP Negeri Kota Salatiga". Teknologi Pendidikan. Vol (1): No. 1:. 83-92.

[3]. Yulitrinisya, W \& Narius, D. (2018). Using Pair Work Technique in Teaching Speaking at Junior High School. English Language Teaching Journal. Vol. (7), No.1: 157-163.

[4]. Santoso, D., \& Anggoro, A. (2019). "Teaching Speaking By Using Quartet Card Game At SPMN 275, East Jakarta". DEIKSIS Journal. Vol (11): No, 1: 28-38.

[5]. Elviza, Y., \& Ratmanida. (2019). The Use of Quartet Cards Game to Develop Junior High School Students' Interest English Speaking ". English Langauge Teaching Journal". Vol (8): No, 1: $146-152$. 